\title{
THE COASTAL \\ CONVECTIVE INTERACTIONS EXPERIMENT (CCIE) Understanding the Role of Sea Breezes for Hailstorm Hotspots in Eastern Australia
}

\author{
by Joshua Soderholm, Hamish McGowan, Harald Richter, KeVin Walsh, \\ Tammy Weckwerth, and Matthew Coleman
}

The influence of the sea-breeze circulation upon thunderstorms in subtropical South East Queensland, Australia, is explored through an 18-yr radar climatology and a two-season field campaign.

$\mathrm{R}$ eoccurrences of high-impact thunderstorms on yearly to decadal time scales quickly become part of "local knowledge" through their long-lasting social and economic impacts. In addition, our current knowledge of thunderstorms has been built from several decades of observational studies, idealized simulations, and full-physics modeling. Despite this accumulating experience, a deeper understanding regarding the presence and drivers of climatological thunderstorm "hotspots" on the mesogamma scale $(2-20 \mathrm{~km})$ is comparatively lacking. In part, this limitation arises from the scarcity of thunderstormresolving observational datasets that extend over a sufficient period of time to provide a robust dataset. From the perspective of community safety and economic interests, a climatological understanding of thunderstorm frequency on a local scale has immediate applications in minimizing vulnerability and refining disaster preparedness. Within Australia, severe thunderstorms alone account for the greatest insured losses among all natural disasters, where damages from individual events often exceed 1 billion
Australian dollars (AUD) (Australian Emergency Management Institute 2014).

For a regional forecaster, an understanding of processes that create climatological thunderstorm hotspots is critical for improving forecasting accuracy and lead time. Numerous environmental features, including topography, sea breezes, and urban heat islands, have been associated with initiating and modifying deep convection (Johnson and Mapes 2001). The diversity of conditioning and trigger processes, especially in regions of significant topography or complex coastlines, limits the applicability of a case study approach for conceptually understanding climatological hotspots. At the other end of the spectrum, previous climatological studies often lack a sufficiently long duration and spatial resolution to quantify storm frequency at scales required to understand local triggering and conditioning processes. Integrating these two approaches into a single methodology is therefore necessary to help close the knowledge gap.

The purpose of this article is twofold. First, it is to demonstrate that significant variability in spatial 
thunderstorm frequency exists on the 2-20-km scale in South East Queensland (SEQ), Australia. South East Queensland is situated on the eastern subtropical coast of Australia comprising coastal and inland relief, urban areas (combined population of 3.4 million), and coastal plains, and the region is well known for frequent warm season thunderstorm activity (Fig. 1). Second, it is to explore the underlying meteorological processes observed during the Coastal Convective Interactions Experiment (CCIE) in an effort to improve the concepts and tools applied for short-term thunderstorm warnings and forecasts. The application of this study extends beyond SEQ to comparable coastal settings globally where warm season thunderstorm activity occurs (e.g., North and South Carolina and the Iberian Peninsula). The complexity of these environments presents a challenge for understanding the mechanisms at work behind thunderstorm hotspots.

\section{SOUTH EAST QUEENSLAND HAILSTORM} CLIMATOLOGY. Thunderstorm climatologies can be developed from a variety of datasets spanning scales from individual cities to the globe. For a robust analysis, the sample size must be sufficiently large to accurately represent thunderstorm track tendencies, particularly for investigating behavior on fine spatial scales. The longest thunderstorm-related records are event-based reports provided by forecasters, media, and the public. This type of data predates all standard meteorological instrumentation used today. For the Australian region, Yeo (2005) and Allen and Karoly (2014) sourced reports from the Australian Bureau of Meteorology (BOM) Severe Storms Archive to investigate severe

AFFILIATIONS: SODERHOLM AND MCGoWAN-Climate Research Group, University of Queensland, St Lucia, Queensland, Australia; RICHTER - Research and Development Branch, Bureau of Meteorology, Melbourne, Victoria, Australia; WALSH—School of Earth Sciences, University of Melbourne, Parkville, Victoria, Australia; WECKWERTH-Earth Observing Laboratory, National Center for Atmospheric Research, Boulder, Colorado; Coleman-Fugro Roames Pty. Ltd., Brisbane, Queensland, Australia CORRESPONDING AUTHOR: Joshua Soderholm, University of Queensland Climate Research Group, Room 527, Level 4, Chamberlain Building (35), Campbell Rd., St. Lucia, QLD 4072, Australia E-mail: j.soderholm@uq.edu.au

The abstract for this article can be found in this issue, following the table of contents.

DOI:10.II75/BAMS-D-14-00212.I

A supplement to this article is available online (10.1175/BAMS-D-14-00212.2)

In final form 17 November 2015

(C2016 American Meteorological Society thunderstorm environments and correlations with climate oscillations (e.g., EL Niño-Southern Oscillation). Because of the sparseness of report sampling in both space and time, the practicality for identifying reoccurring behavior is limited, especially on the mesogamma scales. Furthermore, the determination of thunderstorm severity remains subjective, particularly from public reports. To overcome these sampling issues, thunderstorm climatologies are often constructed from remotely sensed datasets, which provide more uniform and comparatively unbiased coverage. One recent example is the 18 -yr lightning dataset derived from two satellite instruments applied by Dowdy and Kuleshov (2014) to produce lightning density maps for Australia. However, quantification of thunderstorm severity from lightning datasets is limited owing to the complex relationship with convective intensity (Rudlosky and Fuelberg 2013).

One of the most valuable tools for understanding hazards associated with thunderstorms is the weather radar. Within Australia, a network of operational S- and C-band radars has provided surveillance over the past 60 years. The longest continuous archives of volumetric reflectivity for the network are approaching 19 years in length. The addition of modern S-band Doppler weather radars to the network over the past decade provides an archive approaching 7 years in length for the SEQ region, but climatological applications of this comparatively short Doppler dataset remain limited at present. To provide a consistent multiyear analysis for large volumetric datasets, automated algorithms developed for convective nowcasting can be applied. One such algorithm used operationally and for research by the BOM is the Thunderstorms Identification, Tracking, Analysis and Nowcasting (TITAN) package developed by the National Center for Atmospheric Research (Dixon and Wiener 1993). Potts et al. (2000) first demonstrated the capability of TITAN for the greater Sydney region, Australia, to investigate the characteristics of deep convective storms that occurred across 12 thunderstorm days. Building upon this, Peter et al. (2015) applied TITAN to analyze 6 years of continuous radar data for the SEQ region to provide a unique insight into the deep convective properties and regimes. Despite their contributions to developing regional understanding, both of these analyses did not produce high-resolution spatial climatologies of thunderstorms owing to their limited temporal sample size.

For the CCIE climatological analysis, a continuous 18-yr (July 1997 to June 2015) volumetric reflectivity radar dataset was sourced from the $1.9^{\circ} \mathrm{S}$-band weather radar located at Marburg, $50 \mathrm{~km}$ west of Brisbane (Fig. 1). In Australia, the Marburg dataset is of 


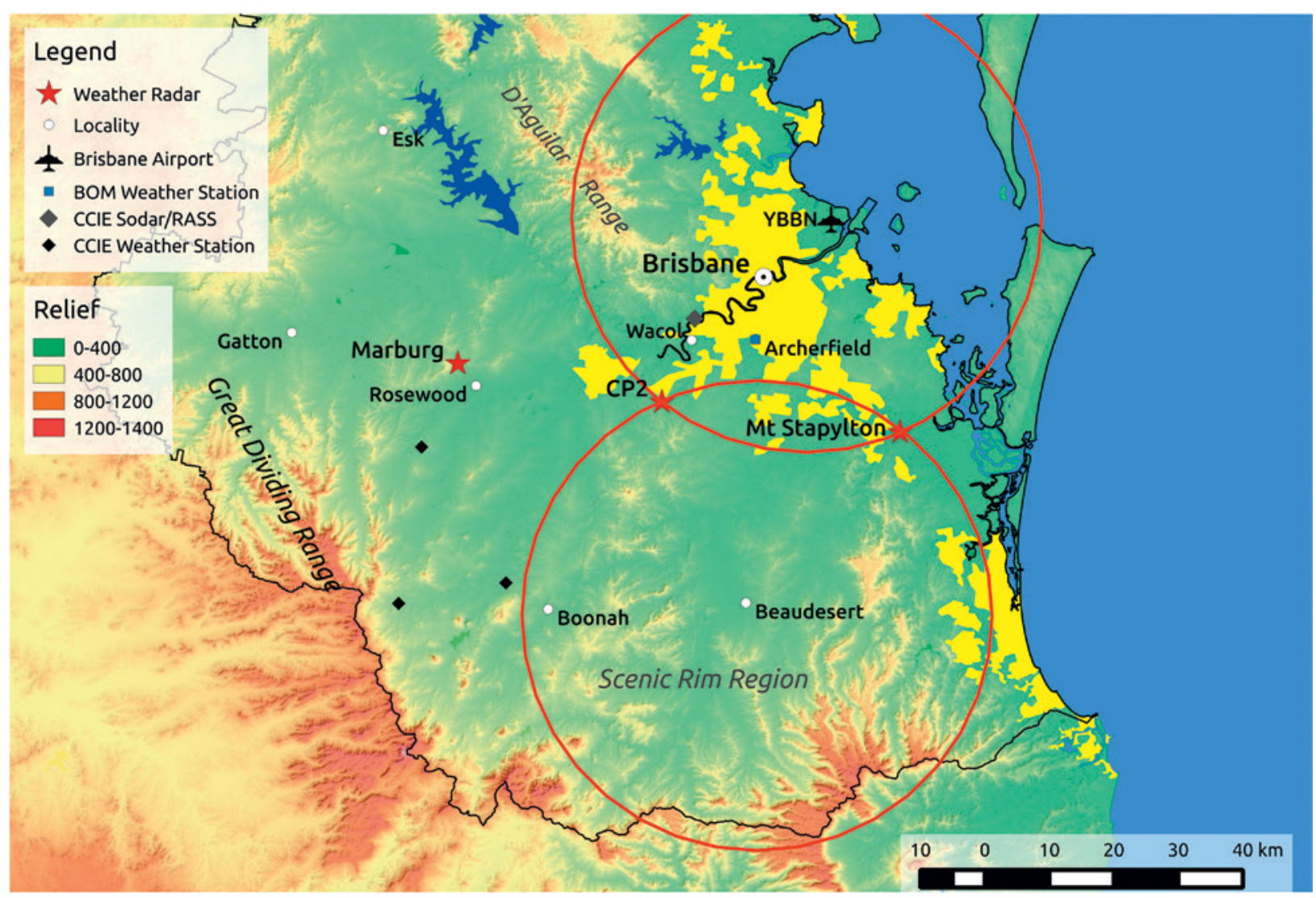

FIG. I. Map of the South East Queensland region, which forms the field site of the CCIE. Locations of fixed instrumentation and selected localities are shown. More densely populated regions are shaded in yellow. The dual-Doppler lobes between CP-2 and Mt. Stapylton are shown with red circles.

unprecedented length, providing a unique opportunity to explore long-term thunderstorm frequency within the region. Because of its central location, this radar provides good coverage across SEQ, including the city of Brisbane. Observations within a $16-\mathrm{km}$ radius of this radar were excluded from the analysis because of the absence of overhead scanning, while data beyond $100 \mathrm{~km}$ in range were excluded because of poor spatial resolution and increasing height of the low-level beam above the surface. A cell-based analysis of this archive was performed using a MATLAB implementation of the identification, tracking, and selected analysis algorithms from the Weather Decision Support SystemIntegrated Information (WDSS-II; Lakshmanan and Smith 2007). The WDSS-II algorithms were selected for their adaptability during cell detection and consistent cell tracking under a variety of storm modes (e.g., linear systems; Lakshmanan and Smith 2010; Lakshmanan et al. 2009). As part of this implementation, $1-\mathrm{km}$ maximum expected size of hail (MESH) grids were generated as a proxy for the actual hail severity (Cintineo et al. 2012). Verification efforts of MESH through the Severe Hazards Verification Experiment (SHAVE) have suggested that MESH has an overforecasting bias and therefore caution must be used when applying it to quantify hail size (Wilson et al. 2009). Cintineo et al. (2012) demonstrated that MESH can, however, provide a useful discriminator between nonsevere and severe hail size (for the previous U.S. severe hail threshold of $19 \mathrm{~mm}$ ) using the MESH values of 21 and $29 \mathrm{~mm}$, respectively. For the purposes of this paper, the lower threshold of $21 \mathrm{~mm}$ is used to include both marginal and severe hail providing cells, thus providing the largest possible climatological sample size.

The 10-min interval of the Marburg radar volumes creates significant spatial discontinuities between MESH grids from an individual thunderstorm. To reduce this effect, MESH grids are converted into binary grids using a threshold filter set at the minimum value $(21 \mathrm{~mm})$ and sequential binary regions along a track are merged (using a convex hull approach) to produce a continuous swath, thus alleviating the discontinuities. By applying the above technique across the entire processed dataset, a spatial climatology of hailstorm frequency can be produced for SEQ. Figure 2a shows local maxima of enhanced hailstorm activity in SEQ. 
The first region extends from the southwest valleys around the township of Boonah (the Scenic Rim region; see Fig. 1) to the north-northeast onto the southern suburbs of Brisbane. A second local maximum in hailstorm frequency occurs on the northern valleys near the town of Esk. Both hotspots are well known to experienced local forecasters as the primary regions for hailstorm activity in SEQ. Initial explanatory hypotheses provided by local forecasters for the more significant Boonah region hotspot centered on the arrival of the sea-breeze front in western SEQ coinciding with the development of thunderstorms on the

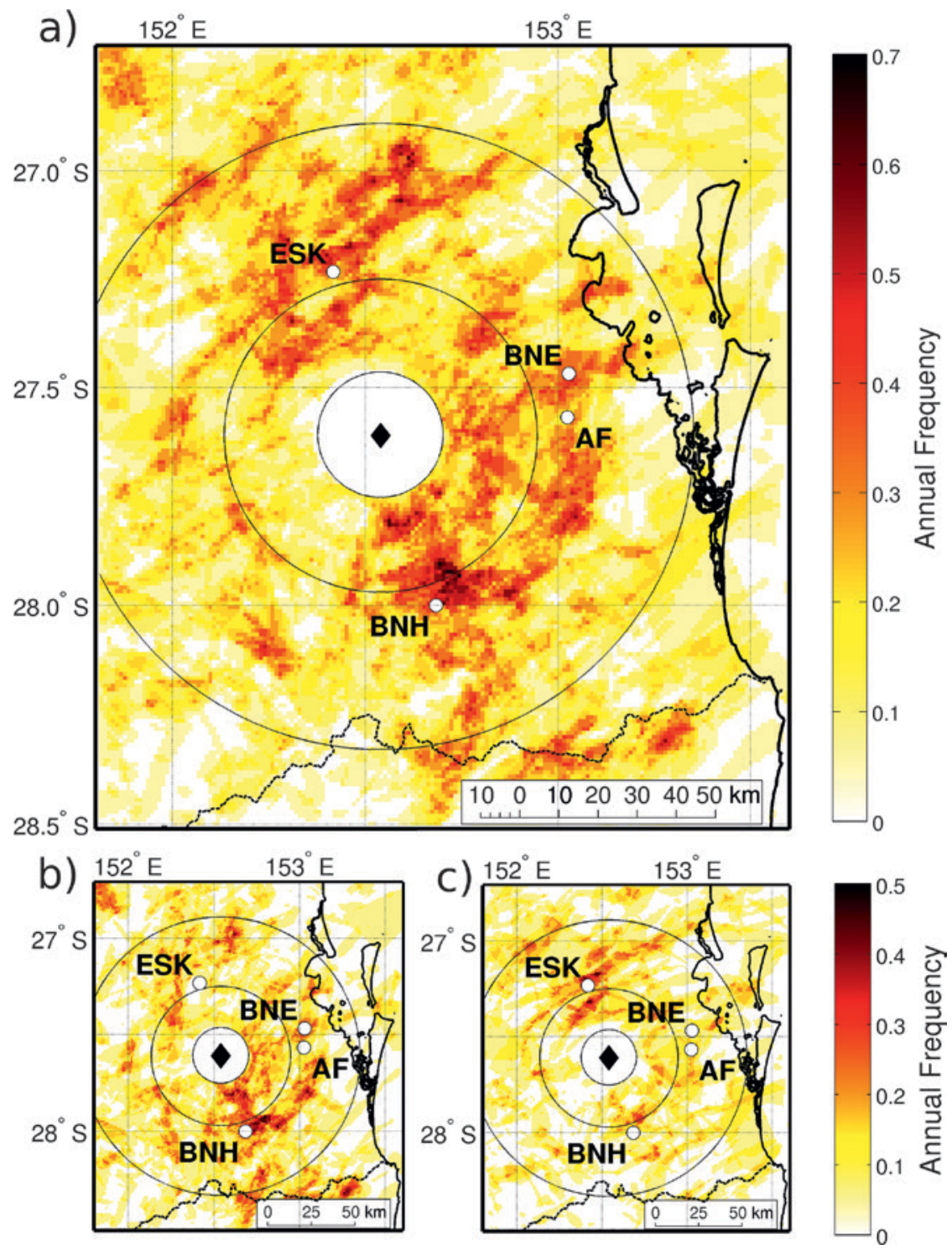

Fig. 2. Annual cumulative MESH swaths (sum of all MESH values averaged by the number of years in the climatology) for $21-\mathrm{mm}$ threshold for (a) all days, (b) sea-breeze days, and (c) non-sea-breeze days. Towns marked include Brisbane (BNE), Archerfield (AF), Boonah (BNH), and Esk (ESK). Marburg radar location marked with black diamond and range rings shown at 16,40 , and $80 \mathrm{~km}$. southern and western ranges and increasing boundary layer favorability for deep convection across this region.

To explore the sea-breeze influence upon hailstorms in SEQ, an automated filter-based algorithm was implemented to identify sea-breeze days using surface weather station observations (Fig. ES1; see online supplement at http://dx.doi.org/ | 0. I I75/BAMS-D- |4-002 I 2.2; Azorin-Molina et al. 2011). The Archerfield weather station was selected for this climatology because of its location in the western suburbs of Brisbane, guaranteeing that the sea-breeze front had propagated at least $25 \mathrm{~km}$ inland from the coastline (Figs. 1 and 2).

Direct detection of the sea breeze in proximity to the Boonah and Esk regions was not achievable owing to the absence of surface weather stations. In comparison to coastal weather stations, the commonly expected temperature drop associated with the passage of the sea-breeze front was often absent for the Archerfield site, presumably owing to enhanced mixing of near-surface air as it propagates onshore (Novak and Colle 2006). Consequently, the filtering process relies on identifying a series of kinematic, moisture, and temporal characteristics of the sea breeze (see online supplement). A verification contingency table (Fig. ES1) estimates that the probability of sea-breeze detection for this method is $81 \%$, with a false alarm rate of $19 \%$. These scores are comparable to the performance of the Azorin-Molina et al. (2011) implementation, indicating that the detection methodology is suitable for SEQ.

Following the detection of 1,893 sea-breeze days (4,316 other days) across the 18 -yr period, the hailstorm climatology was divided accordingly. A clear change in the spatial hailstorm frequency is apparent where 
hailstorms in the Boonah region are more frequent on sea-breeze days and suppressed on non-sea-breeze days (Figs. 2b,c). In contrast, hailstorms within the Esk region remain relatively unaffected by the presence of sea-breeze activity. The Froude number of a 500 -m-deep sea-breeze front moving at $5 \mathrm{~m} \mathrm{~s}^{-1}$ for the 700-800-m-high D'Aguilar Ranges (see Fig. 1 for location) remains $<<1$, indicating topographic blocking would occur of onshore flow into the Esk region. No significant topography impedes the propagation of the sea breeze into the Boonah region from the northeast. This preliminary analysis suggests that the sea-breeze circulation and associated large-scale conditions influence the spatial distribution of hailstorms over SEQ.

\section{EXPERIMENT MOTIVATION AND STRAT-}

EGY. The initiation of deep convection along the seabreeze front convergence zone is a well-documented phenomenon (e.g., Miller 2003; Fovell 2005). Florida, in particular, has hosted extensive field programs to investigate this process (e.g., Atkins et al. 1995; Wilson and Megenhardt 1997; Kingsmill 1995), of which some cases have been simulated numerically (e.g., Dailey and Fovell 1999; Nicholls et al. 1991); however, concepts developed for this low-lying peninsula, which commonly produces converging sea breezes from the west and east coasts, have limited application for continental coastlines with significant inland topography. The physical setting found along much of eastern Australia is such that deep convection is most frequently initiated by the Great Dividing Range and lesser coastal ranges (see Fig. 1 for location). Under prevailing upper-level westerly steering flow, these storms then move onto the coastal plains where they often interact with the sea-breeze front and postfrontal air mass, in contrast to storms initiating along the sea-breeze front. Numerous reports over the past 30 years have documented this mode of interaction in association with the highest-impact thunderstorm events for the Sydney and Brisbane regions, which resulted in cumulative insured losses exceeding 10 billion AUD (Holcombe and Moynihan 1978; Harper and Callaghan 1998; Richter et al. 2014; Australian Emergency Management Institute 2014; Callaghan 1996). Despite the historical significance of sea-breeze-cold pool interactions for eastern Australia, research remains limited to a small body of anecdotal case studies.

To understand how the sea-breeze interaction can modify existing thunderstorms, it must be considered with respect to the fundamental ingredients for deep convection-namely, the role of buoyancy and shear (e.g., Doswell 2001). Relative to the western continental air mass (in SEQ), the sea breeze is generally considered as cool, moist, and stable. However, modification of the sea breeze via entrainment of warming near-surface air during overland flow promotes increased buoyancy (Simpson et al. 1977). Subtle changes in boundary layer stability are known to have significant effects upon the likelihood of initiating thunderstorms (Weckwerth et al. 2008; Weckwerth 2000). In addition to modifying buoyancy, the sea breeze generally augments the magnitude of nearsurface vertical shear normal to the coastline (east to northeasterlies), typically opposing in direction to shear generated by the cold pool forward flank (eastern edge) for thunderstorms moving under prevailing ambient westerly to southwesterly steering flow. The net tendency from these opposing shear profiles potentially promotes deeper lift along the cold pool interface, particularly for environments lacking strong ambient low-level environmental shear (e.g., Rotunno et al. 1988; Thorpe et al. 1982). Furthermore, enhanced convection has also been documented observationally for colliding gravity currents (e.g., Karan and Knupp 2009; May 1999; Wilson and Megenhardt 1997). The hypothesized kinematic and thermodynamic processes that take place during an interaction reside at spatial scales that are difficult to accurately initialize or reproduce in numerical models for individual events; therefore, an intensive observational approach was considered necessary.

The field campaign phase of the CCIE was designed to capture both the properties of the thunderstorm (particularly its cold pool) and the local environment, prior to and following an interaction with the sea breeze. Field work was conducted across two warm seasons: the first extending from 20 November 2013 until 31 January 2014 and the second period from 15 October 2014 to 31 January 2015. The network of BOM-operated radars, automatic weather stations, and a radiosonde facility in SEQ formed the backbone of the CCIE. Furthermore, the radars include the polarimetric dual-wavelength (S and X band) CP-2 radar and the operational Mt. Staplyton S-Band Doppler radar (Fig. 1). The close proximity of CP-2 to the thunderstorm hotspots identified in SEQ, and its exemption from operational surveillance duties, prioritizes the radar as a core instrument for the experiment. Building upon the existing BOM network, additional instrumentation was deployed in mobile and static configurations. To complement the Brisbane Airport (YBBN) radiosonde profiles of the sea breeze close to the coast, a sonic detection and ranging (sodar) wind profiler and a radio acoustic sounding system (RASS) array were deployed on the western fringe of Brisbane, $30 \mathrm{~km}$ inland (Table 1, Fig. 1). A lack of BOM automatic 
weather stations throughout the Boonah thunderstorm hotspot prompted the deployment of three additional stations in this region to improve monitoring of seabreeze penetration and inland airmass characteristics.

In comparison to a sea breeze, the propagation and geographic regularity of thunderstorms is considerably less predictable, presenting a significant challenge for in situ observations. Over the last two decades, the international community has met this challenge through the use of mobile instrumentation, in particular the use of mobile weather radar (e.g., Wurman et al. 2012; Weckwerth et al. 2004). In an Australian first, a mobile pulsed Doppler lidar was deployed for the 2013/14 field campaign and a mobile polarimetric X-band radar (UQ-XPOL) was operated for the 2014/15 campaign (Fig. 3, Table 1). Given that winds behind a gravity current boundary such as sea breezes or gust fronts are generally perpendicular to the boundary, radial winds observed at low-elevation angles in scans aligned normal to the front would be expected to closely approximate the true wind velocity (Wakimoto 1982). This range-height indicator (RHI) scanning strategy was utilized extensively by CP-2, the mobile lidar, and UQ-XPOL to capture the vertical wind structure for application to the aforementioned shear balance arguments. Complementary mobile

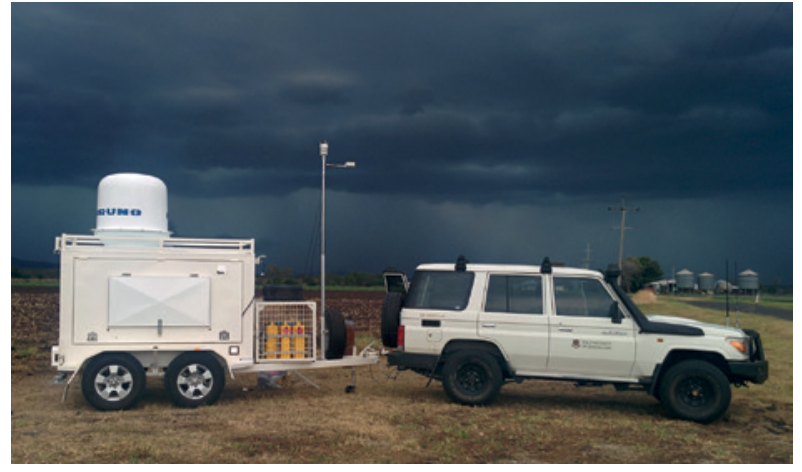

Fig. 3. Photograph of the mobile $X$-band dual-polarized radar deployed with mobile weather station at Gatton, SEQ (see Fig. I), on 26 Nov 2014.

thermodynamic observations were collected by a truck GPS sounding system and automatic weather station. Thunderstorms developing in the Boonah region that were expected to interact with the sea-breeze circulation were prioritized targets for CP-2 and the mobile instrumentation during CCIE operations.

\section{HIGHLIGHTS OF PRELIMINARY FINDINGS.}

The fine temporal and spatial resolution datasets collected during CCIE, particularly from the CP-2, mobile UQ-XPOL radar, and Doppler lidar instruments,

TABLE I. Summary of instrument and sensors for the CCIE.

\begin{tabular}{|c|c|c|c|c|}
\hline $\begin{array}{l}\text { Platform/ } \\
\text { instrument }\end{array}$ & Operator & $\begin{array}{l}\text { Manufacturerl } \\
\text { sensor/type }\end{array}$ & $\begin{array}{l}\text { Sampling } \\
\text { strategy }\end{array}$ & Season \\
\hline $\begin{array}{l}\text { Doppler scanning } \\
\text { lidar }\end{array}$ & University of Queensland & Leosphere WLIO0S & Targeted RHI & I \\
\hline UQ-XPOL & University of Queensland & $\begin{array}{l}\text { Furuno WR2100 (dual } \\
\text { polarized) }\end{array}$ & Targeted RHI & 2 \\
\hline $\mathrm{CP}-2$ & $\begin{array}{l}\text { Centre for Australian } \\
\text { Weather and Climate } \\
\text { Research }\end{array}$ & $\begin{array}{l}\text { NCAR (dual polarized, } \\
\text { dual frequency; } X \text { and } \\
S \text { band) }\end{array}$ & $\begin{array}{l}\text { Sequenced tar- } \\
\text { geted RHI and } \\
\text { PPI scanning }\end{array}$ & 2 \\
\hline $\begin{array}{l}\text { Mt. Stapylton } \\
\text { radar }\end{array}$ & Bureau of Meteorology & $\begin{array}{l}\text { Meteor I500 (S-band } \\
\text { Doppler) }\end{array}$ & $\begin{array}{l}\text { 6-min volumet- } \\
\text { ric cycle }\end{array}$ & Both \\
\hline Marburg radar & Bureau of Meteorology & WSR74 (S band) & $\begin{array}{l}\text { 10-min volumet- } \\
\text { ric cycle }\end{array}$ & Both \\
\hline Sodar profiler & University of Queensland & Scintec AG MFAS & Continuous & Both \\
\hline RASS profiler & University of Queensland & Scintec AG RAEI & Continuous & Both \\
\hline $\begin{array}{l}\text { Radiosonde } \\
\text { system }\end{array}$ & $\begin{array}{l}\text { Brisbane Airport office, } \\
\text { Bureau of Meteorology }\end{array}$ & $\begin{array}{l}\text { Vaisala Inc. RS92 } \\
\text { DigiCora }\end{array}$ & $\begin{array}{l}0000 \text { UTC and } \\
\text { on request }\end{array}$ & Both \\
\hline $\begin{array}{l}\text { Mobile radiosonde } \\
\text { system }\end{array}$ & University of Queensland & $\begin{array}{l}\text { Vaisala Inc. RS92 } \\
\text { DigiCora }\end{array}$ & $\begin{array}{l}0200 \text { UTC and } \\
\text { on request }\end{array}$ & 2 \\
\hline $\begin{array}{l}\text { Truck weather } \\
\text { station }\end{array}$ & University of Queensland & Vaisala Inc. WTX520 & $\begin{array}{l}\text { Targeted de- } \\
\text { ployment }\end{array}$ & Both \\
\hline Weather stations & University of Queensland & HOBOnet Systems & $\begin{array}{l}\text { Three fixed } \\
\text { deployments }\end{array}$ & Both \\
\hline Weather stations & Bureau of Meteorology & Various & Continuous & Both \\
\hline
\end{tabular}


highlight the complexity that inherently occurs at the mesogamma scale of cold pool-sea-breeze interactions. Here three examples are presented for different conditions: 1 ) the pulsed advance of a sea-breeze front on 28 November 2013,2 ) a multicell thunderstorm cold pool on 27 December 2013, and 3) a collision between a sea breeze and a squall-line cold pool on 11 December 2014.

Pulsed sea breeze of 28 November 2013. On $28 \mathrm{No-}$ vember 2013, the sea-breeze front was observed $31 \mathrm{~km}$ west of the coastline using the mobile pulsed Doppler lidar in the Brisbane suburb of Wacol (see Fig. 1). Lidar RHI scans through the sea breeze show turbulent flow, particularly around $1300 \mathrm{~m}$ (Fig. 4b). Rather than propagating as a single front, a staggered passage of three temporally coherent seabreeze pulses was observed over a period of $28 \mathrm{~min}$, each separated by a region of weak flow (Fig. ES2). Each pulse decreased in depth (1250 to $750 \mathrm{~m}$ ) and increased in inbound velocity $\left(4\right.$ to $8 \mathrm{~m} \mathrm{~s}^{-1}$ ) at a periodicity of approximately 10 min until the arrival of the stable maritime flow. In addition to these postfrontal oscillations, the scalloped boundary between the inbound gravity current and outbound return flow aloft suggests possible Kelvin-Helmholtz wave activity (e.g., Plant and Keith 2007; Chiba 1997). Kelvin-Helmholtz wave activity is also evident along the leading edge of the sea-breeze front in the 0304:49 UTC RHI (Fig. ES2). Puygrenier et al. (2005) noted that a complex physical setting (complex coastline, urbanized terrain, topography), similar to SEQ, is related to the pulsed behavior of the sea-breeze flow. This deviation from the standard gravity current description of a sea-breeze front must be considered during an interaction with a thunderstorm cold pool.
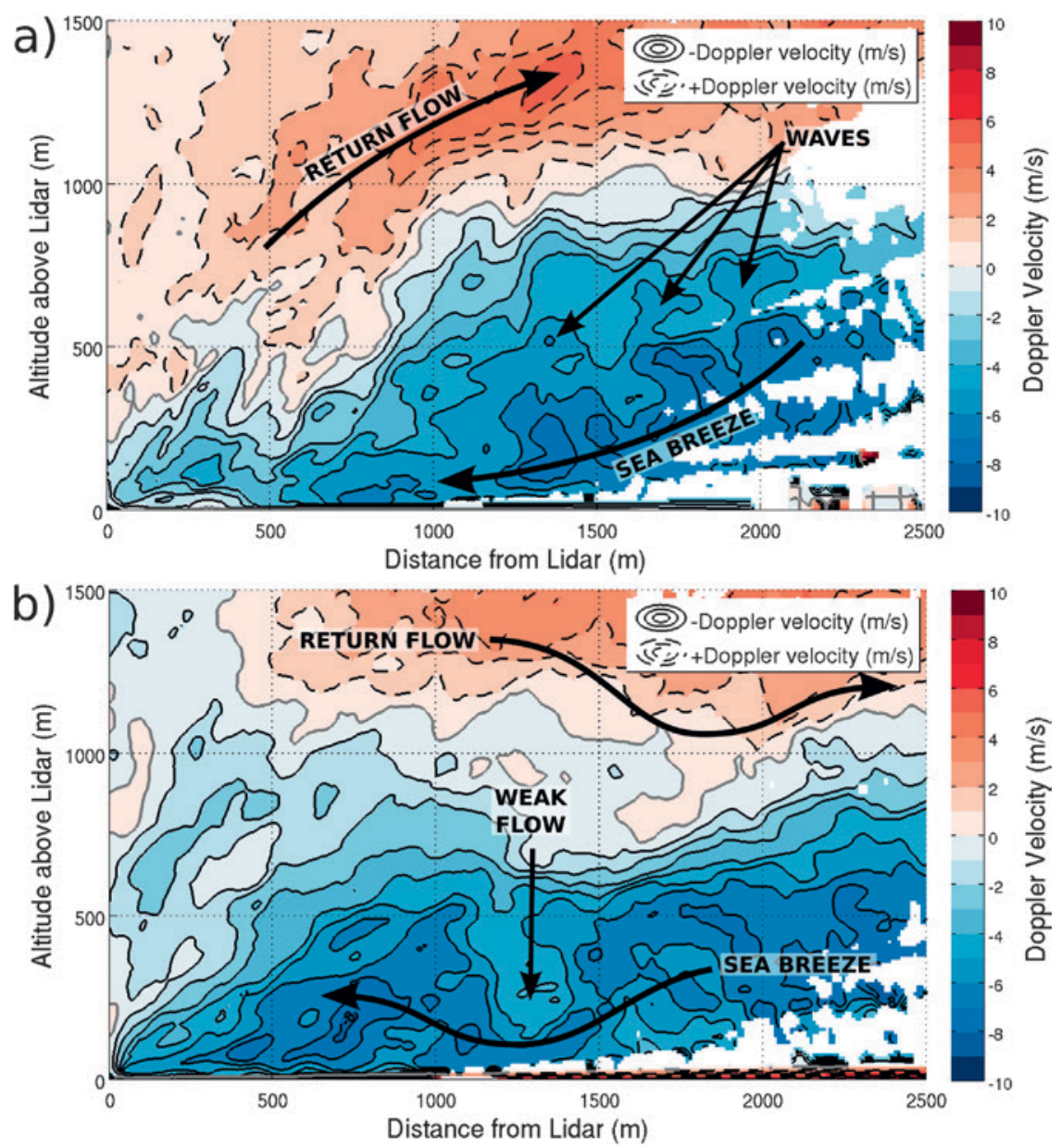

FIg. 4. Vertical cross sections of Doppler lidar radial velocity for a sea-breeze front advancing from the southwest (right)-(left) at (a) 031 0:07 and (b) 0325:50 UTC 28 Nov 2013 at $-27.583^{\circ}$ S, $152.933^{\circ} \mathrm{E}$ (Wacol locality; Fig. I) at an RHI azimuth of $42^{\circ}$ true north (TN). Inbound radial velocities are shaded in blue with solid contour lines; outbound radial velocities are shaded in red with dashed contour lines (contour intervals are I $\mathrm{m} \mathrm{s}^{-1}$ ). The zero velocity isodop is shown in gray and arrows approximating the radial flow path shown in black.

Multicell thunderstorm cold pool on 27 December 2013. Thunderstorm cold pools are in a constant state of evolution from the initial downdraft to the dissipation of the convective cell and the radially outward propagation of the gust front (e.g., Wilson and Megenhardt 1997; Wakimoto 1982). Doppler lidar observations of a multicell thunderstorm at Rosewood (see Fig. 1 for location) on 27 December 2013 demonstrate this constant state of evolution. Marginal instability (CAPE of $1296 \mathrm{~J} \mathrm{~kg}^{-1}$ ) and $0-6-\mathrm{km}$ shear $\left(8 \mathrm{~m} \mathrm{~s}^{-1}\right)$ observed by the Brisbane Airport 0000 UTC radiosonde release was indicative of a marginal multicell environment, suggesting cold pool evolution would be highly variable. In this case, two gust fronts were initially observed in the 0320:22 UTC scan: a maturing gust front on the upshear side of the cold pool exhibiting a tight velocity gradient at 
$1500 \mathrm{~m}$ from the lidar propagating into an older, less intense outflow region (Fig. 5a). Ninety seconds later, the maturing gust front collapsed from $500 \mathrm{~m}$ to approximately $250 \mathrm{~m}$ and the distinct boundary was lost as it merged with the existing gust front (Figs. 5b and ES3). Furthermore, an emerging convective downdraft evident in Fig. $5 \mathrm{~b}$ leads to the deepening of the multicell cold pool from 250 to $500 \mathrm{~m}$ at 0325:08 UTC. This case highlights the rapid evolution of the cold pool depth and intensity on minute time scales. This variability again creates significant uncertainty that must be considered when analyzing and predicting interactions with an advancing sea-breeze front.

Collision between a sea breeze and a thunderstorm cold pool on II December 20/4. The sea-breeze-thunderstorm cold pool interaction observed during CCIE on
11 December 2014 occurred approximately $50 \mathrm{~km}$ inland, a comparable distance to the majority of events observed throughout the two field campaigns. To explore the overland evolution of the sea breeze, three vertical wind profiles from various data sources were sampled along a northeast-to-southwest transect (Fig. 6a). Starting from the northeast at Brisbane Airport, an onshore wind profile derived from the 0300 UTC (1300 local time) radiosonde shows a distinct low-level maximum of $12.5 \mathrm{~m} \mathrm{~s}^{-1}$ at $200 \mathrm{~m}$ within the 1200 -m-deep onshore component $\left(60^{\circ}\right)$ of the sea-breeze circulation (red dashed profile in Fig. $6 \mathrm{~b}$ ). The next transect profile was observed $28 \mathrm{~km}$ to the southwest of Brisbane Airport using sodar/RASS instrumentation at 0330 UTC (orange dashed-dotted profile in Fig. 6b). Across this heavily urbanized segment of the transect, the sea breeze experienced a reduction in surface wind speed
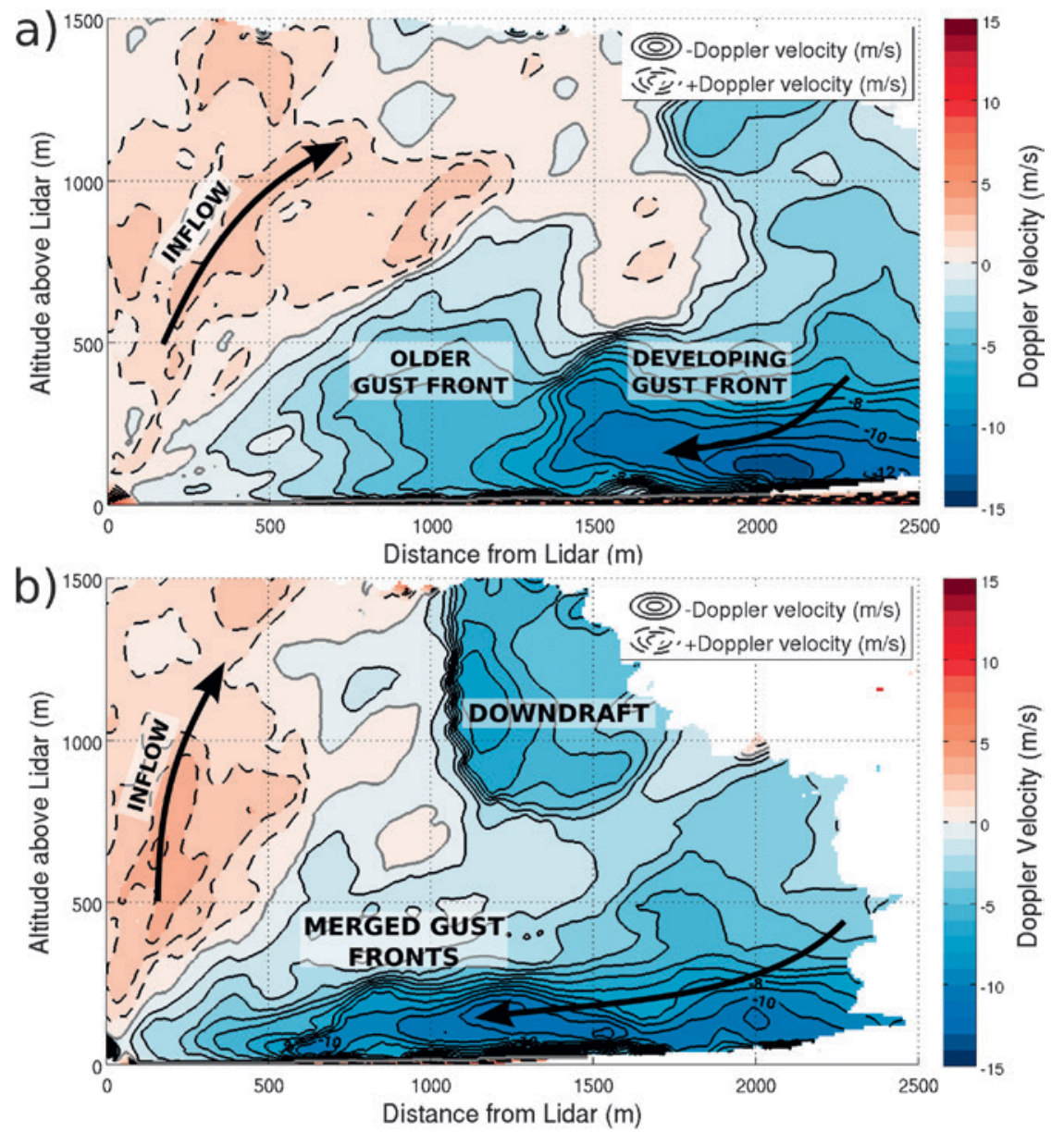

FIG. 5. Velocity cross sections of Doppler lidar radial velocity for a thunderstorm gust front at (a) 0320:22 and (b) 032I:58 UTC 27 Dec 20I3 at $-27.643^{\circ} \mathrm{S}$, I52.567 $\mathrm{E}$ (Rosewood locality; Fig. I) at an RHI azimuth of $187.7^{\circ} \mathrm{TN}$. Inbound radial velocities are shaded in blue with solid contour lines; outbound radial velocities are shaded in red with dashed contour lines (contour intervals are I $\mathrm{m} \mathrm{s}^{-1}$ ). The zero velocity isodop is shown in gray and arrows approximating the radial flow path are shown in black. by approximately $50 \%$ to $5 \mathrm{~m} \mathrm{~s}^{-1}$. As previously noted in the pulsed sea-breeze case study (28 November 2013), it is hypothesized that the increased surface roughness and urban heat island circulations across the city landscape contributed toward this modification of the sea breeze (Puygrenier et al. 2005). A final vertical wind profile was reconstructed using a CP-2 vertical crosssectional scan orientated $242^{\circ}$, opposite to the onshore component, at 0341 UTC (yellow profile in Fig. 6b). This profile was extracted within the sea-breeze air mass, immediately to the northeast of the cold pool gust front to provide a close proximity wind profile representative of the interacting sea breeze. This profile shows limited change from the sodar profile $11 \mathrm{~min}$ earlier, suggesting the sea breeze had reached a more steady kinematic state of inland propagation over the final 15-km segment (Fig. 6b).

Prior to the sea-breeze interaction, the UQ-XPOL mobile radar was deployed 

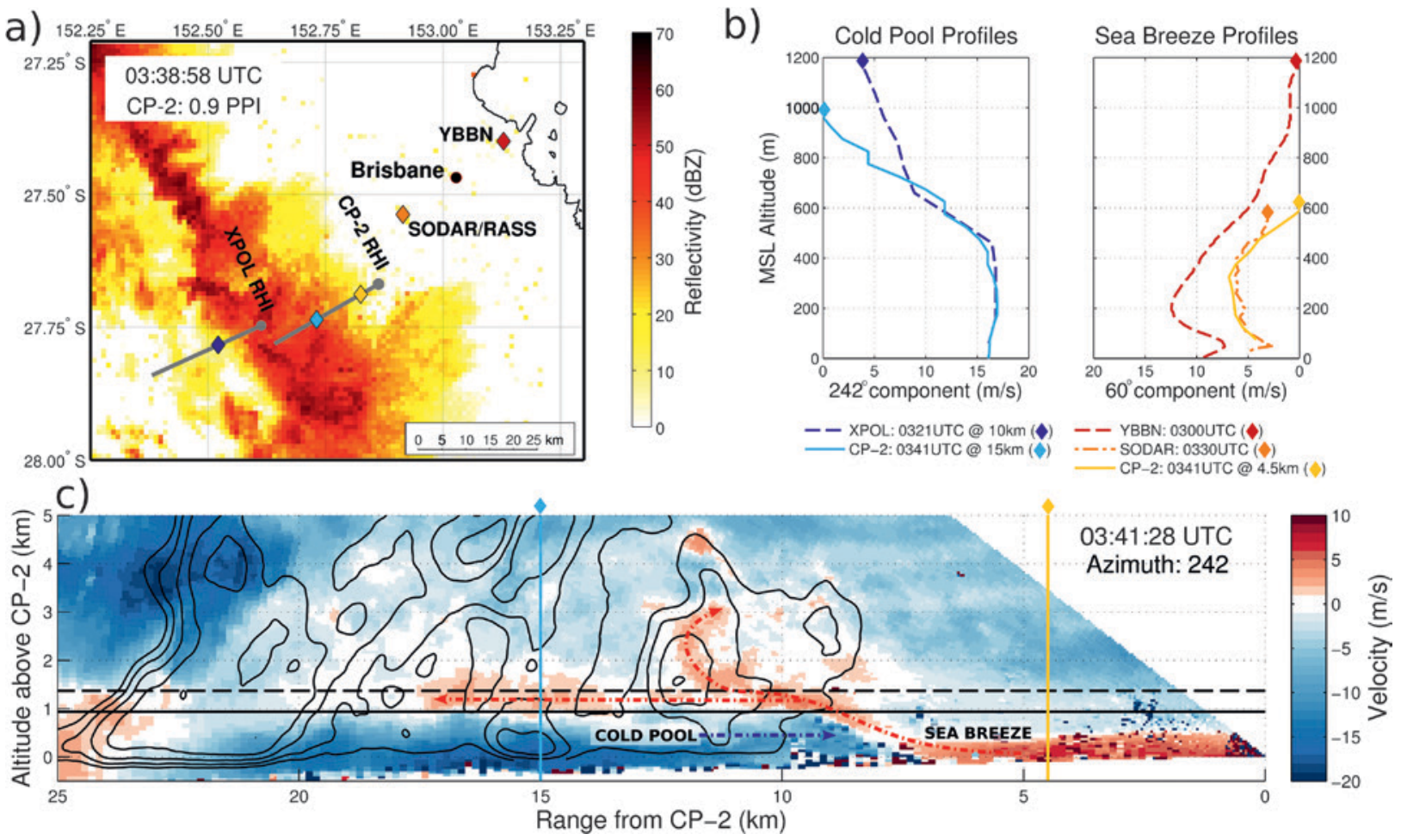

FIG. 6. Analysis of a sea breeze and cold pool features on II Dec 20I4. (a) The $0.9^{\circ}$ reflectivity PPI from CP-2 radar at 0338 UTC with the locations of XPOL and CP-2 RHI scans (gray dots and lines) and associated vertical profiles (colored diamonds) shown. (b) Vertical profiles of the cold pool wind speed $\left(242^{\circ}\right.$ component) based on CP-2 and XPOL and the sea-breeze wind speed (60 component) based on CP-2, airport radiosonde (YBBN), and sodar observations. Colored diamonds associated with each vertical wind profile from (a) are shown in the legend and plot. (c) The CP-2 RHI at 034 I UTC with shaded radial velocity and contoured reflectivity from 35 dBZ in 5-dBZ steps. Level of free convection for the sea-breeze (pre-sea-breeze) air parcel is shown with a dashed (solid) line. Colored lines and diamonds indicate the locations of profiles extracted from the CP-2 RHI for (a) and (b).

$12 \mathrm{~km}$ south of Rosewood (Fig. 1) to observe the cold pool structure and dynamics. Analogous to CP-2, boundary-normal vertical cross-sectional scans (Fig. 6a) were utilized to provide a precollision cross section of the cold pool structure. Between the 0321 UTC UQ-XPOL scan and the 0341 UTC CP-2 scan, the cold pool shear and depth appear unchanged (blue profiles in Fig. $6 \mathrm{~b}$ ). Such steady cold pool behavior is dissimilar to the rapid evolution observed in the 27 December 2013 lidar case study (Figs. 5a,b). This continuity, in addition to the separation of the gust front from the convective cells (not shown for XPOL), suggests that the cold pool was in the later stages of its life cycle (Wakimoto 1982). A mobile sounding launched $10 \mathrm{~km}$ north of Boonah at 0230 UTC (not shown) indicates that the level of free convection (LFC) for an inland pre-sea-breeze parcel was $986 \mathrm{~m}$, approximately the same as the cold pool depth (Fig. 6c). Modifying this sounding using post-seabreeze observations from Archerfield weather station at 0300 UTC increased the LFC to $1251 \mathrm{~m}$, above the depth of the cold pool induced lift (Fig. 6c). CP-2 radar observed the cooler $\left(22^{\circ} \mathrm{C}\right)$ cold pool air collide with and lift the warmer $\left(28^{\circ} \mathrm{C}\right)$ sea breeze at 0330:02 UTC (not shown). At 0341:28 UTC a shallow 50-dBZ region is evident behind (southwest of) the cold pool gust front head in the CP2 RHI (Fig. 6c) owing to lifting in the region; however, the lofted sea breeze primarily manifested itself as horizontal flow above the cold pool. Kingsmill (1995) observed a similar lack of ascent above the cold pool following a sea-breeze interaction and attributed this to a reduction in gust front depth. In contrast, no significant changes in gust front depth were observed immediately following the sea-breeze collision for the 11 December 2014 case study (Fig. 6b).

Following the sea-breeze collision, the prestorm surface to $1-\mathrm{km}$ wind profile directed normal to the cold pool $(\Delta \mathrm{u})$ transitioned from a weakly sheared environment $\left(2.7 \mathrm{~m} \mathrm{~s}^{-1}\right)$ in the 0210 UTC sounding profile at Boonah (not shown) to stronger shear $\left(7.7 \mathrm{~m} \mathrm{~s}^{-1}\right)$ in the 0341:28 UTC CP-2 RHI. Rotunno et al. (1988) showed 
that conditions for deep updrafts are optimized as the net vorticity generated in the low-level shear balances the net buoyant vorticity from the cold pool. The thunderstorm cold pool boundarynormal shear $(\Delta \mathrm{u})$ at the time of collision (0341:28 UTC) was $18.9 \mathrm{~m} \mathrm{~s}^{-1}$ through the surface to $1-\mathrm{km}$ layer, suggesting that the sea-breeze environment was more optimal for updrafts than the prestorm environment. A conceptual schematic of the circulation tendencies associated with the sea breeze and cold pool shear is shown in Fig. 7 before and after the collision. Despite this potential for deeper lifting, sea-breeze air struggled to lift, possibly owing to the elevated LFC, resulting in the rapid dissipation of deep convection as it crossed the sea-breeze boundary (Fig. 7b).

Field operations summary. This selection of case studies from the two-season CCIE campaign highlights the complex evolution of both the sea-breeze circulation and thunderstorm cold pools and difficulties present for understanding interactions between these air masses at the subkilometer and minute scales. Continued analysis of events observed throughout the campaign is expected to outline a spectrum of sea-breeze collision responses in thunderstorm convective behavior. Particular attention will be paid to the spatial distribution of favorable and unfavorable interactions with respect to the Boonah climatological thunderstorm hotspot. The CCIE was also fortunate enough to operate for the severe 27 November 2014 hailstorm event, which developed in a sea-breeze air mass. Insured damage from this single event has exceeded 1.34 billion AUD for the Brisbane city region (Insurance Council of Australia 2015), mainly because of giant hail; however, convective interactions were not directly observed and the event will require careful reanalysis to understand the mechanisms operating.
CONCLUSIONS. The CCIE's integration of climatological analysis with an intensive field campaign has provided an opportunity for revealing some of the complexities surrounding thunderstorm hotpots in complex physical settings like SEQ. A preliminary analysis indicates a strong relationship between the presence of the sea breeze and the Boonah hailstorm hotspot, but further analysis is needed to isolate the additional influence of synoptic and topographic drivers. Furthermore, finescale field observations of the seabreeze-thunderstorm interaction events have begun to shed some light on the meteorology of thunderstorm hotspots in SEQ. The future application of the concepts developed by the CCIE to sea-breeze forecasts based on high-resolution operational numerical weather prediction models is expected to improve operational nowcasting of events such as the 27 November 2014 
hailstorm. We hope the novel methodology and insight this article provides into localized hailstorm hotspots will motivate further research into similar anomalies worldwide for thunderstorm-prone environments.

ACKNOWLEDGMENTS. We thank Furgo Roames Pty Ltd, the University of Queensland (UQ), and the Australian Bureau of Meteorology Research and Development Branch for funding the purchase of instrumentation and operational expenses. Additionally, instrument acquisition support and expertise were provided by Leosphere and Furuno Co. Ltd. The authors also acknowledge the Brisbane regional forecasting office of the $\mathrm{BOM}$ for providing additional radiosonde releases and forecasting guidance during field operation days. Use of the CP-2 radar was provided as an in-kind contribution by CAWCR with the assistance of Ken Glasson. We thank external volunteers and those from the University of Queensland for assisting in field operations. Support for publication costs was provided by UQ, CAWCR, NCAR, Roames, and the University of Melbourne. The National Center for Atmospheric Research is sponsored by the National Science Foundation.

\section{REFERENCES}

Allen, J., and D. Karoly, 2014: A climatology of Australian severe thunderstorm environments 1979-2011: Inter-annual variability and ENSO influence. Int. J. Climatol., 34, 81-97, doi:10.1002/joc.3667.

Atkins, N., R. Wakimoto, and T. Weckwerth, 1995: Observations of the sea-breeze front during CaPE. Part II: Dual-Doppler and aircraft analysis. Mon. Wea. Rev., 123, 944-969, doi:10.1175/1520 -0493(1995)123<0944:OOTSBF>2.0.CO;2.

Australian Emergency Management Institute, 2014: Disaster information. Accessed 17 July 2015. [Available online at www.emknowledge.gov.au/disaster -information/.]

Azorin-Molina, C., S. Tijm, and D. Chen, 2011: Development of selection algorithms and databases for sea breeze studies. Theor. Appl. Climatol., 106, 531-546, doi:10.1007/s00704-011-0454-4.

Bryan, G., R. Rotunno, and M. Weisman, 2004: What is RKW theory? 26th Conf. on Severe Local Storms, Nashville, TN, Amer. Meteor. Soc., 4B.6. [Available online at https://ams.confex.com/ams/26SLS /webprogram/Manuscript/Paper211731/bryan _rotunno_weisman_2012.pdf.]

Callaghan, J., 1996: Review of severe thunderstorm forecasting and the severe thunderstorm warning service in the Southeast Coast district of Queensland. Extended Abstract, Fifth Australian Severe Thunderstorm Conf., Avoca Beach, NSW, Australia,
Australian Bureau of Meteorology, 178. [Available online at www.bom.gov.au/library/.]

Chiba, O., 1997: Variability of the sea-breeze front from SODAR measurements. Bound.-Layer Meteor., 82, 165-174, doi:10.1023/A:1000216406527.

Cintineo, J. L., T. M. Smith, V. Lakshmanan, H. E. Brooks, and K. L. Ortega, 2012: An objective highresolution hail climatology of the contiguous United States. Wea. Forecasting, 27, 1235-1248, doi:10.1175/ WAF-D-11-00151.1.

Dailey, P. S., and R. G. Fovell, 1999: Numerical simulation of the interaction between the sea-breeze front and horizontal convective rolls. Part I: Offshore ambient flow. Mon. Wea. Rev., 127, 858-878, doi:10.1175/1520 -0493(1999) $127<0858$ :NSOTIB>2.0.CO;2.

Dixon, M., and G. Wiener, 1993: TITAN: Thunderstorm Identification, Tracking, Analysis, and Nowcasting-A radar-based methodology. J. Atmos. Oceanic Technol., 10, 785-797, doi:10.1175/1520 -0426(1993)010<0785:TTITAA >2.0.CO;2.

Doswell, C. A., III, 2001: Severe convective storms-An overview. Severe Convective Storms, Meteor. Monogr., No. 50, Amer. Meteor. Soc., 1-26.

Dowdy, A. J., and Y. Kuleshov, 2014: Climatology of lightning activity in Australia: Spatial and seasonal variability. Aust. Meteor. Oceanogr. J., 64, 103-108.

Fovell, R. G., 2005: Convective initiation ahead of the sea-breeze front. Mon. Wea. Rev., 133, 264-278, doi:10.1175/MWR-2852.1.

Harper, B., and J. Callaghan, 1998: Modelling of severe thunderstorms in South East Queensland. Extended Abstract, Sixth Australian Severe Storms Conf., Bardon, QLD, Australia, Australian Bureau of Meteorology, 152. [Available online at www.bom.gov.au/library/.]

Holcombe, G., and G. Moynihan, 1978: An investigation of the Brisbane tornado of 4 November 1973. Meteorological Note 97, 27 pp. [Available online at www.bom.gov.au/library/.]

Insurance Council of Australia, 2015: Disaster statistics. Accessed 2 November 2015. [Available online at www.tiki-toki.com/timeline/entry/568110/Ten -Years-of-Catastrophe/.]

Johnson, R. H., and B. E. Mapes, 2001: Mesoscale processes and severe convective weather. Severe Convective Storms, Meteor. Monogr., No. 50, Amer. Meteor. Soc., 71-122.

Karan, H., and K. Knupp, 2009: Radar and profiler analysis of colliding boundaries: A case study. Mon. Wea. Rev., 137, 2203-2222, doi:10.1175/2008MWR2763.1.

Kingsmill, D. E., 1995: Convection initiation associated with a sea-breeze front, a gust front, and their collision. Mon. Wea. Rev., 123, 2913-2933, doi:10.1175/1520 -0493(1995)123<2913:CIAWAS>2.0.CO;2. 
Lakshmanan, V., and T. Smith, 2007: The Warning Decision Support System-Integrated Information. Wea. Forecasting, 22, 596-612, doi:10.1175/WAF1009.1.

— and _ 2010: An objective method of evaluating and devising storm-tracking algorithms. Wea. Forecasting, 25, 701-709, doi:10.1175/2009WAF2222330.1.

_ , K. Hondl, and R. Rabin, 2009: An efficient, general-purpose technique for identifying storm cells in geospatial images. J. Atmos. Oceanic Technol., 26, 523-537, doi:10.1175/2008JTECHA1153.1.

May, P., 1999: Thermodynamic and vertical velocity structure of two gust fronts observed with a wind profiler/RASS during MCTEX. Mon. Wea. Rev., 127, 1796-1807, doi:10.1175/1520-0493(1999)127<1796:TA VVSO $>2.0 . \mathrm{CO} ; 2$.

Miller, S., 2003: Sea breeze: Structure, forecasting, and impacts. Rev. Geophys., 41, 1011, doi:10.1029/2003RG000124.

Nicholls, M., R. A. Pielke, and W. Cotton, 1991: A twodimensional numerical investigation of the interaction between sea breezes and deep convection over the Florida peninsula. Mon. Wea. Rev., 119, 298-323, doi:10.1175/1520-0493(1991)119<0298:ATDNIO>2 .0.CO;2.

Novak, D. R., and B. A. Colle, 2006: Observations of multiple sea breeze boundaries during an unseasonably warm day in metropolitan New York City. Bull. Amer. Meteor. Soc., 87, 169-174, doi:10.1175 /BAMS-87-2-169.

Peter, J. R., M. J. Manton, R. J. Potts, P. T. May, S. M. Collis and L. Wilson, 2015: Radar-derived statistics of convective storms in Southeast Queensland. J. Appl. Meteor. Climatol., 54, 1985-2008, doi:10.1175 /JAMC-D-13-0347.1.

Plant, R. S., and G. J. Keith, 2007: Occurrence of Kelvin-Helmholtz billows in sea-breeze circulations. Bound.-Layer Meteor., 122, 1-15, doi:10.1007 /s10546-006-9089-x.

Potts, R. J., T. D. Keenan, and P. T. May, 2000: Radar characteristics of storms in the Sydney area. Mon. Wea. Rev., 128, 3308-3319, doi:10.1175/1520 -0493(2000)128<3308:RCOSIT>2.0.CO;2.

Puygrenier, V., F. Lohou, B. Campistron, F. Saïd, G. Pigeon, B. Bénech, and D. Serça, 2005: Investigation on the fine structure of sea-breeze during ESCOMPTE experiment. Atmos. Res., 74, 329-353, doi:10.1016/j. atmosres.2004.06.011.

Richter, H., J. Peter, and S. Collis, 2014: Analysis of a destructive wind storm on 16 November 2008 in Brisbane, Australia. Mon. Wea. Rev., 142, 3038-3060, doi:10.1175/MWR-D-13-00405.1.

Rotunno, R., J. Klemp, and M. Weisman, 1988: A theory for strong, long-lived squall lines. J. Atmos. Sci., 45,
463-485, doi:10.1175/1520-0469(1988)045<0463:AT FSLL>2.0.CO;2.

Rudlosky, S. D., and H. E. Fuelberg, 2013: Documenting storm severity in the mid-Atlantic region using lightning and radar information. Mon. Wea. Rev., 141, 3186-3202, doi:10.1175/MWR-D-12-00287.1.

Simpson, J., D. Mansfield, and J. Milford, 1977: Inland penetration of sea-breeze fronts. Quart. J. Roy. Meteor. Soc., 103, 47-76, doi:10.1002/qj.49710343504.

Thorpe, A. J., M. Miller, and M. W. Moncrieff, 1982: Two-dimensional convection in non-constant shear: A model of mid-latitude squall lines. Quart. J. Roy. Meteor. Soc., 108, 739-762, doi:10.1002 /qj.49710845802.

Wakimoto, R., 1982: The life cycle of thunderstorm gust fronts as viewed with Doppler radar and rawinsonde data. Mon. Wea. Rev., 110, 1060-1082, doi:10.1175/1520-0493(1982)110<1060:TLCOTG $>2.0 . \mathrm{CO} ; 2$.

Weckwerth, T., 2000: The effect of small-scale moisture variability on thunderstorm initiation. Mon. Wea. Rev., 128, 4017-4030, doi:10.1175/1520 -0493(2000)129<4017:TEOSSM>2.0.CO;2.

— ternational $\mathrm{H}_{2} \mathrm{O}$ Project (IHOP_2002) and some preliminary highlights. Bull. Amer. Meteor. Soc., 85, 253-277, doi:10.1175/BAMS-85-2-253.

-, H. V. Murphey, C. Flamant, J. Goldstein, and C. R. Pettet, 2008: An observational study of convection initiation on 12 June 2002 during IHOP_2002. Mon. Wea. Rev., 136, 2283-2304, doi:10.1175/2007MWR2128.1. Wilson, C. J., K. L. Ortega, and V. Lakshmanan, 2009: Evaluating multi-radar, multi-sensor hail diagnosis with high resolution hail reports. 25th Conf. on International Interactive Information and Processing Systems (IIPS) for Meteorology, Oceanography, and Hydrology, Phoenix, AZ, Amer. Meteor. Soc., P2.9. [Available online at https://ams.confex.com/ ams/89annual/techprogram/paper_146206.htm.]

Wilson, J., and D. Megenhardt, 1997: Thunderstorm initiation, organization, and lifetime associated with Florida boundary layer convergence lines. Mon. Wea. Rev., 125, 1507-1525, doi:10.1175/1520 -0493(1997)125<1507:TIOALA >2.0.CO;2.

Wurman, J., D. Dowell, Y. Richardson, P. Markowski, E. Rasmussen, D. Burgess, L. Wicker, and H. B. Bluestein, 2012: The Second Verification of the Origins of Rotation in Tornadoes Experiment: VORTEX2. Bull. Amer. Meteor. Soc., 93, 1147-1170, doi:10.1175/BAMS-D-11-00010.1.

Yeo, C., 2005: Severe thunderstorms in the Brisbane region and a relationship to the El Niño Southern Oscillation. Aust. Meteor. Mag., 54, 197-202. 